\title{
Productivity and morphological composition of Xaraés palisade grass under three light intensities
}

\section{Produtividade e composição morfológica do capim-xaraés em três intensidades luminosas}

\author{
Vinicius Carreteiro Gomes ${ }^{1 *}$; Juliana da Silva Barros ${ }^{1}$; Paulo Roberto de Lima \\ Meirelles $^{2}$; Ciniro Costa ${ }^{2}$; Erikelly Aline Ribeiro de Santana ${ }^{3}$; Cristiano Magalhães \\ Pariz $^{4}$; Daniel Martins de Sousa ${ }^{1}$; André Michel de Castilhos ${ }^{5}$
}

\begin{abstract}
The adaptation of Urochloa brizantha to Brazilian ecosystems and the use of artificial shading in low light production studies are important tools to obtain productive responses and to know the behavior of plants when used in integration with arboreal components. The experiment was conducted at the FMVZ - UNESP in Botucatu city, São Paulo state, Brazil. The study aimed to evaluate the yield of $U$. brizantha (syn Brachiaria brizantha) cv. Xaraés (Xaraés palisade grass) under three light intensities and four cuts. The experimental design was a randomized block with three treatments (natural luminosity, 30\% light reduction, and $60 \%$ light reduction), three replicates and four cuts. The following morphological components were determined: leaf area index (LAI), forage accumulation rate (FAR), total forage mass (TFM), stem yield (SY), leaf yield (LY), and dead material yield (DMY). Light intensity influenced grass productivity, and the best performance was reached under $60 \%$ shading, which had higher values of TFM, LY, SY, LAI, and FAR if compared to natural luminosity. Thus, a reduction of $60 \%$ in light intensity showed to be the most productive and the best alternative under those conditions.
\end{abstract}

Key words: Artificial shading. Forage accumulation. Light interception.

\section{Resumo}

A adaptação da Urochloa brizantha aos ecossistemas brasileiros e a utilização de sombreamento artificial em estudos de produção sob baixas luminosidades são ferramentas importantes para se obter respostas produtivas e conhecer o comportamento das plantas quando utilizadas em integrações com componentes arbóreos. O experimento foi conduzido na FMVZ - UNESP Botucatu, com objetivo de avaliar a produtividade da cultivar de Urochloa brizantha (syn Brachiaria brizantha) cv. Xaraés submetida a três intensidades luminosas e quatro cortes. O delineamento experimental foi em blocos ao acaso, sendo os tratamentos: luminosidade natural, redução de $30 \%$ e $60 \%$ de luz, com três repetições e

1 Discentes, Programa de Pós-Graduação em Zootecnia, Universidade Estadual Paulista “Júlio de Mesquita Filho", FMVZ/ UNESP, Botucatu, SP, Brasil. E-mail: vinicius2gomes@gmail.com, juliana.1234barros@gmail.com, souzadm.zoo@gmail.com

2 Profs Drs, FMVZ/UNESP, Departamento de Melhoramento e Nutrição Animal, Botucatu, SP, Brasil. E-mail: paulo.meirelles@, unesp.br, ciniro.costa@unesp.br

$3 \operatorname{Prof}^{\mathrm{a}} \mathrm{Dr}^{\mathrm{a}}$, Universidade de Guarulhos, UNG, Guarulhos, SP, Brasil. E-mail: erikellysantana@hotmail.com

4 Pesquisador Pós Dr,", FMVZ/UNESP, Departamento de Melhoramento e Nutrição Animal, Botucatu, SP, Brasil. E-mail: cmpzoo@gmail.com

5 Zootecnista Dr., FMVZ/UNESP, Departamento de Melhoramento e Nutrição Animal, Botucatu, SP, Brasil. E-mail: michel. castilhos@unesp.br

* Author for correspondence 
quatro cortes. Foi realizada a separação morfológica, índice de área foliar e a taxa de acúmulo, também foi calculada a produção de massa seca total, colmo e folhas, além da produção de material morto. A produtividade foi influenciada pelos níveis de intensidade de luz, sendo o melhor desempenho obtido no tratamento com $60 \%$ de sombreamento, que apresentou maior produção de massa seca total, de folha e colmo, índice de área foliar e maior taxa de acúmulo em comparação ao pleno sol. O tratamento com $60 \%$ de redução de luminosidade foi o mais produtivo, sendo o melhor tratamento nestas condições.

Palavras-chave: Acúmulo de forragem. Interceptação luminosa. Sombreamento artificial.

\section{Introduction}

In Brazil, grazing lands occupy 158 million hectares. Of this, about 111 million ha are cultivated pasture (IBGE, 2018), of which around 70 million are grown only with a cultivar of an exotic apomictic species, Urochloa brizantha (syn Brachiaria brizantha) cv. Marandu (COSTA et al., 2009). In this context, silvopastoral systems (SSPs) are advantageous alternatives to replace the current pasture ecosystems (forage grass monoculture), thus developing a more economically and environmentally sustainable activity (FRANKE et al., 2001).

Silvopastoral systems have been highlighted as an alternative to improve soil physical and chemical properties (NEVES et al., 2009), forage nutritive value, and animal performance (PACIULLO et al., 2011), besides reducing financial risks and increasing income (MÜLLER et al., 2011). These systems have spread to several regions of Brazil, mostly cultivated with forages of the genus Urochloa (BRIGHENTI et al., 2014).

In some cases, the presence of arboreal-shrub species may impair forage growth by shading and competition for water and nutrients; therefore, shading tolerance may be a differential factor for the success of a SSP. For this reason, studies on lowlight forage production using artificial shading are beneficial for simulating plant productive responses and behavior before use in SPPs.

Furthermore, for good results in a crop-livestockforestry integration, forage species should be selected based on their ability to develop well under shading. So, it is of great importance to check forage tolerance to low-light intensity and select species with a good productive capacity (above 4,000 kg ha$\left.{ }^{1}\right)$ and adapted to the handling and soil and climate conditions of the sites where they will be planted (ANDRADE et al., 2003; GOBBI et al., 2009).

Among the tropical forages grown in Brazil, cultivar Xaraés, of the genus Urochloa, is indicated for cultivation in soils of medium fertility, good drainage, and medium texture. In field trials, this cultivar has presented high forage yield, reaching $21 \mathrm{t} \mathrm{ha}^{-1}$ dry mass (VALLE et al., 2004), with a faster regrowth after grazing compared to the cultivar Marandu (JANK et al., 2005). The pure seed yield of Xaraés reaches around $120 \mathrm{~kg} \mathrm{ha}^{-1}$ per year (VALLE et al., 2004) and has also shown a good biomass production under shading (SOUTO et al., 2009).

Given the above, our objective was to compare the yield and morphological composition of cultivar Xaraés, U. brizantha (syn Brachiaria brizantha), under three luminous intensities (natural and under 30 and $60 \%$ of artificial shading).

\section{Materials and Methods}

The experiment was conducted at the Department of Forage Production, Lageado Experimental Farm, in the School of Veterinary Medicine and Animal Science (FMVZ/ UNESP) in Botucatu city - SP, Brazil. Meteorological data referring to the experimental period were provided by the Department of Natural Resources of the School of Agricultural Sciences (FCA/UNESP), also in Botucatu. The gauge station is located about 900 $\mathrm{m}$ from the experiment area. Figure 1 shows the meteorological data (rainfall; average, maximum, 
and minimum temperatures; and 60-year average temperatures).

Local soil is classified as a dystrophic Red Latosol according to the Brazilian Soil Classification System of the Brazilian Agricultural Research Corporation (EMBRAPA, 2013). Before the beginning of the experiment, soil samples were collected according to the method recommended by EMBRAPA (2011).

Figure 1. Meteorological data (rainfall; average, maximum, and minimum temperatures; and 60-year average temperatures) for the experimental period, recorded in a gauge station of the FCA/UNESP, in Botucatu city, São Paulo state, Brazil (2015).

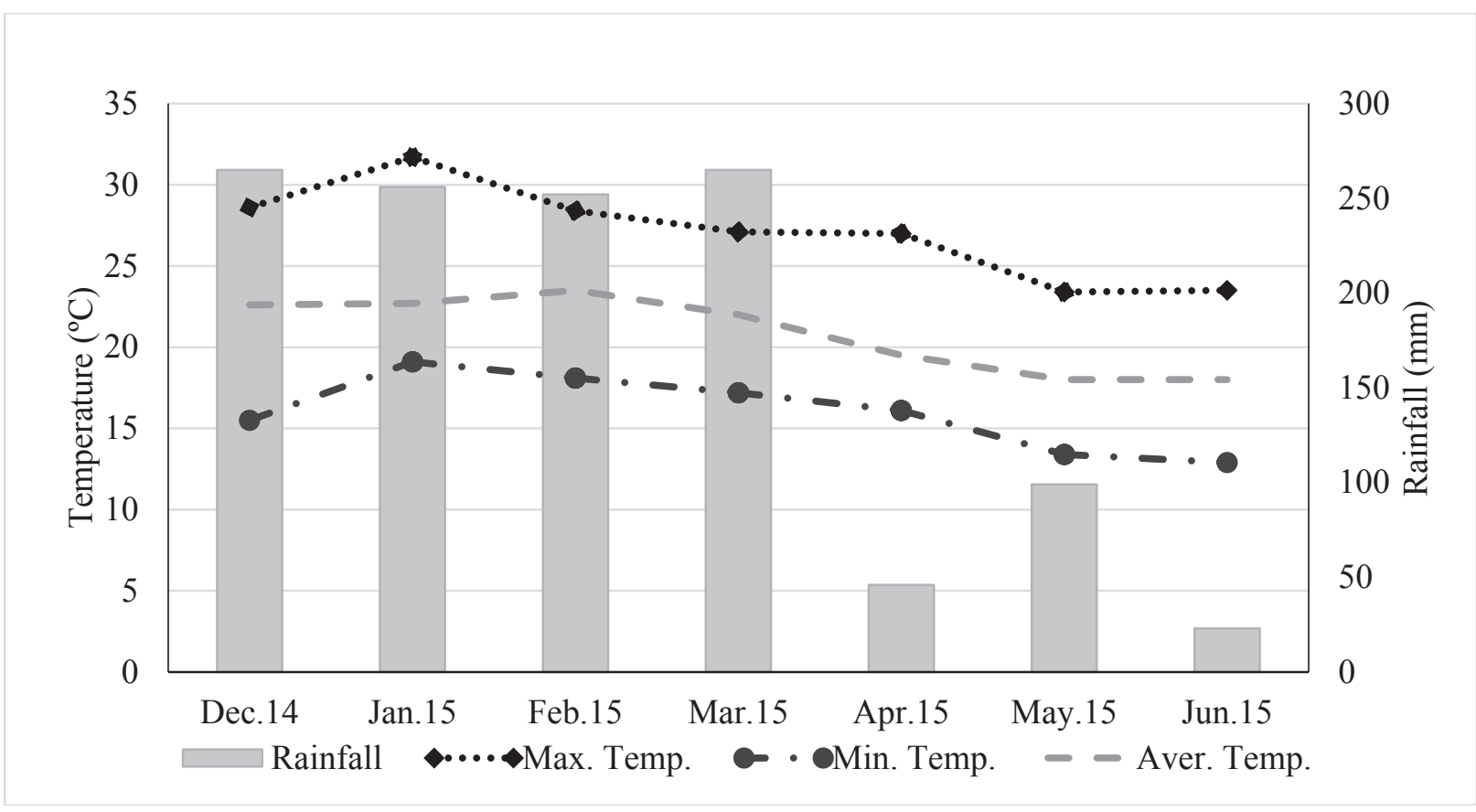

The results of soil sampling $(0-20 \mathrm{~cm})$ were: $\mathrm{pH}(\mathrm{CaCl}): 5.55$, organic matter: $30.5 \mathrm{~g} . \mathrm{dm}^{3}, \mathrm{P}$ (resin): $14 \mathrm{mg} \cdot \mathrm{dm}^{-3}, \mathrm{~S}: 8.5 \mathrm{mg} \cdot \mathrm{dm}^{-3}, \mathrm{~V}: 71 \%$, and cation exchange capacity (CEC): $79.5 \mathrm{mmol}_{\mathrm{c}} \cdot \mathrm{dm}^{-3}$. In addition, the contents of $\mathrm{Ca}, \mathrm{Mg}$, and $\mathrm{K}$ were of 38, 17, and $1.3 \mathrm{mmol} . \mathrm{dm}^{-3}$, respectively. After soil analysis, fertilization was carried out applying 200 $\mathrm{kg} \mathrm{ha}^{-1}$ of NPK formulated fertilizer (20-00-20) to meet plant requirements.

Grasses of cultivar Xaraés (Urochloa brizantha) were used in an experiment with randomized block design, with blocks consisting of three shading intensities (treatments) and four forage cuts, and four replicates. Thus, treatments consisted of three light intensities (full sun, 30\% shading, and 60\% shading). Each plot measured $4 \mathrm{~m}$ x $5 \mathrm{~m}\left(20 \mathrm{~m}^{2}\right)$ and had a net area of $3 \mathrm{~m} \mathrm{x} 4 \mathrm{~m}\left(12 \mathrm{~m}^{2}\right)$.

The experimental area under full sun was already in place and was sown in rows spaced $25 \mathrm{~cm}$ apart (16 five-meter rows per plot), using a sowing density of $5 \mathrm{~kg}$ pure and viable seeds per hectare. This area was managed with fertilization and periodic forage cuttings.

Standardization cuts were carried out at $15 \mathrm{~cm}$ above soil surface. Soon after, the plots were covered with artificial shading to reduce the luminosity, using black plastic screens (SOMBRITE®; black garden netting) of 30 and $60 \%$ incident solar radiation interception.

Additionally, four cuts were made to evaluate each treatment. These cuts were performed when 
Xaraés grass reached $95 \%$ of light interception under screens (Table 1). Luminosity measurements were made at different points, above and below canopy, to estimate light interception (LI) using a photosynthetically active radiation (PAR) meter (AccuPAR model LP-80 PAR / LAI). This measure was determined according to the following equation:

$$
\mathrm{LI}=[(\text { PAR under canopy }) \div(\text { PAR above canopy })] \times 100
$$

Measurements were made every three days until the recommended LI (95\%) was reached. When reached, forage was cut at ground level, removing all plants within a $0.25 \mathrm{~m}^{2}$ quadrat $(0.5 \mathrm{~m} \times 0.5 \mathrm{~m})$, thrown into each plot. After cutting, samples of forage were weighed and homogenized per plot.

Table 1. Dates and interval between Xaraés-grass cuttings under three light intensities.

\begin{tabular}{lcccccccc}
\hline \multirow{2}{*}{ Treat. } & \multicolumn{4}{c}{ Cut dates } & \multicolumn{4}{c}{ Cut Intervals (days) } \\
\cline { 2 - 8 } & $1^{\text {st }}$ & $2^{\text {nd }}$ & $3^{\text {rd }}$ & $4^{\text {th }}$ & $1^{\text {st }}$ & $2^{\text {nd }}$ & $3^{\text {rd }}$ & $4^{\text {th }}$ \\
\hline $0 \%$ & $01 / 05 / 15$ & $02 / 10 / 15$ & $03 / 06 / 15$ & $04 / 11 / 15$ & 25 & 36 & 25 & 36 \\
$30 \%$ & $01 / 05 / 15$ & $02 / 10 / 15$ & $03 / 06 / 15$ & $04 / 17 / 15$ & 25 & 36 & 25 & 42 \\
$60 \%$ & $01 / 15 / 15$ & $03 / 06 / 15$ & $05 / 04 / 15$ & $06 / 15 / 15$ & 35 & 51 & 59 & 42 \\
\hline
\end{tabular}

0\%: Xaraés palisade grass under full sun; 30\%: Xaraés palisade grass under 30\% shading; 60\%: Xaraés palisade grass under $60 \%$ shading.

After each sampling, another standardization cut was made at $15 \mathrm{~cm}$ above the soil surface. Thereafter, the experimental units received nitrogen (N) and potassium (K) fertilizations, using an NPK formulated fertilizer (20-00-20), at the same amount used after standardization cut (200 kg ha-1).

For morphological analyses, the following plant components were manually separated: leaves (with more than $50 \%$ green surface), stems (stem and sheath of tillers with or without inflorescence), and dead material (necrotic leaf tissue attached to tillers and any completely necrotic material nonvisibly adhered to tillers). After separation, these components were dried in an oven with forced air circulation at $65{ }^{\circ} \mathrm{C}$ for $72 \mathrm{~h}$ (until reaching constant weight), and then samples were weighed for dry matter (DM) determination.

Green mass production per area was determined using measures of forage weight from cutting zone, converting to $\mathrm{kg} \mathrm{ha}^{-1}$. The production of total forage mass (TFM) per area was obtained by multiplying green mass production by the respective DM content of each plot. Leaf, stem, and dead material yields (LY, SY, and DMY) were obtained by multiplying the green mass production of these components by their respective DM contents.

Forage accumulation rate (FAR) was estimated for each cycle by dividing the TFM $\left(\mathrm{kg} \mathrm{ha}^{-1}\right)$ produced during each period by the time interval between cuts. Leaf-stem ratio (LSR) was determined by dividing the DM yields of leaves and stems. Leaf area index (LAI) was defined as leaf surface per soil area unit, which was measured by an indirect method between 11.00 am and $01.00 \mathrm{pm}$, using a canopy analyzer and photosynthetically active radiation meter (AccuPAR model LP-80 PAR / $\mathrm{LAI}$ ). The readings were performed at ground level, in all plots before each cut.

All data were initially tested for normality by the Shapiro-Wilk's test using UNIVARIATE procedure of SAS software version 9.4 (SAS Institute, Cary, NC, USA) (SAS, 2014). The data were also tested for sphericity by the Bartlett's test using FACTOR procedure of SAS version 9.4 (SAS, 2014). The 
results indicated a normal distribution ( $\mathrm{W}>0.90)$ and no sphericity. All variables were analyzed using the PROC MIXED procedure of SAS and Satterthwaite approximation to determine the denominator degrees of freedom for the tests of fixed effects. The effects of treatments, cuts, and all resulting interactions were considered as fixed. The data were analyzed using 'block' (shading x cuts) as random effect. The statistical model used for the analysis of forage production and morphological composition encompassed the main effects of treatment. Each cut represented one replicate, and the covariance structure used for all replicates was composite symmetry (CS), which provided the best fit for analyses according to the Akaike information criterion. Results were referred as minimum squares and separated using the probability of differences (PDIFF function), and effects were considered as statistically significant at $\mathrm{p} \leq 0.05$.

\section{Results and Discussion}

As expected, light interception (LI) showed no differences for the studied parameters (Table 2), since it was established as a criterion to perform forage cuts every three days, until $95 \%$ LI was reached.

Table 2. Productive response from Xaraés palisade grass cutting under levels of light intensity.

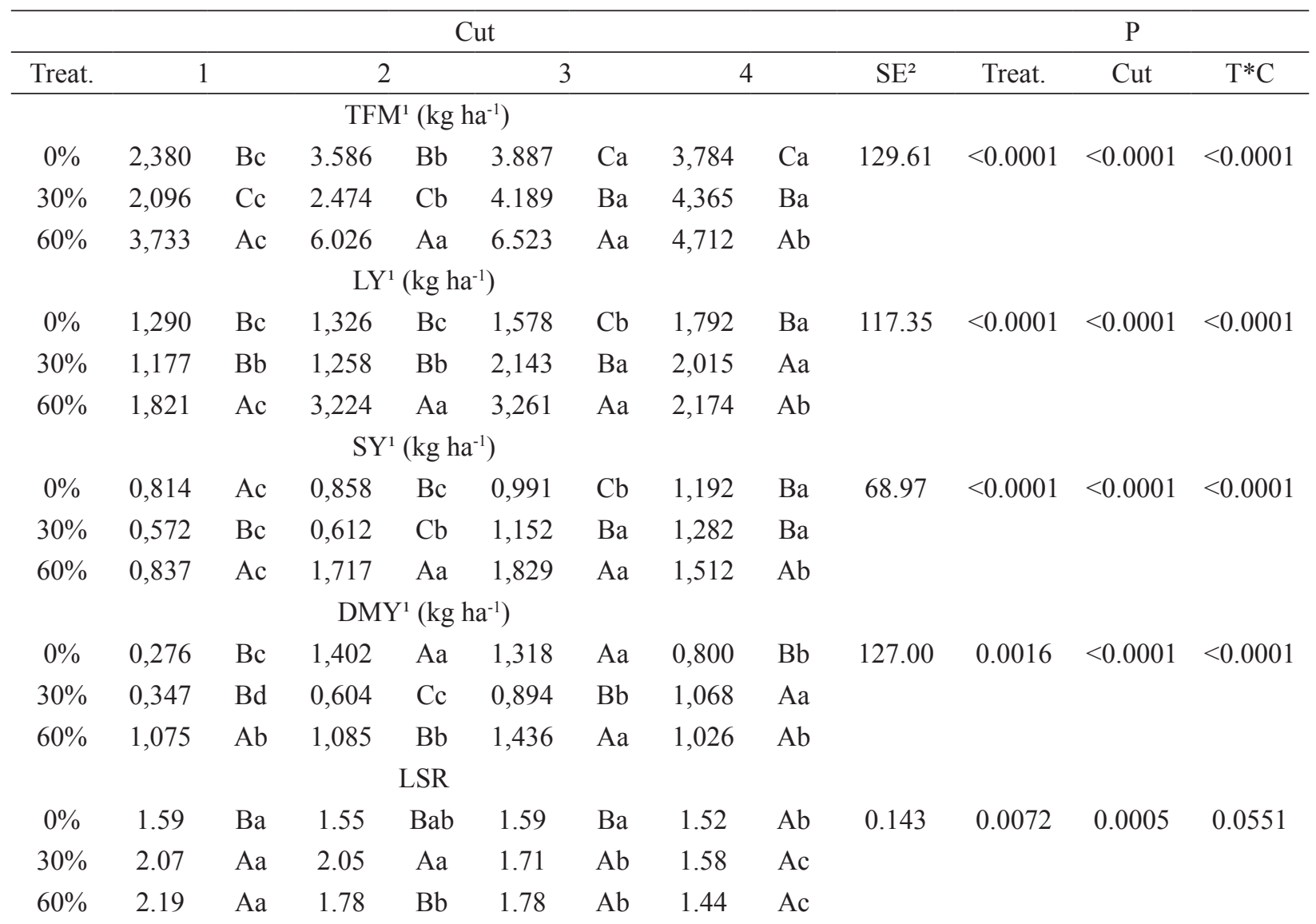

continue 
continuation

\begin{tabular}{ccccccccccccc}
\multicolumn{10}{c}{ LAI $\left(\mathrm{cm}^{3}\right)$} & & & \\
$0 \%$ & 2.06 & $\mathrm{Cb}$ & 1.85 & $\mathrm{Cc}$ & 2.30 & $\mathrm{Ca}$ & 1.82 & $\mathrm{Cc}$ & 0.31 & $<0.0001$ & 0.0392 & $<0.0001$ \\
$30 \%$ & 2.93 & $\mathrm{Bb}$ & 2.27 & $\mathrm{Bc}$ & 3.23 & $\mathrm{Aa}$ & 2.72 & $\mathrm{Bb}$ & & & & \\
$60 \%$ & 4.16 & $\mathrm{Aa}$ & 4.43 & $\mathrm{Aa}$ & 3.21 & $\mathrm{Ab}$ & 3.05 & $\mathrm{Ab}$ & & & & \\
& & & & $\mathrm{LI}(\%)$ & & & & & & & & \\
$0 \%$ & 94 & & 93 & & 94 & & 93 & & 1.71 & 0.6844 & 0.5436 & 0.8033 \\
$30 \%$ & 95 & & 93 & & 93 & & 94 & & & & & \\
$60 \%$ & 93 & & 94 & & 93 & & 95 & & & & & \\
\hline
\end{tabular}

${ }^{1}$ Values corrected to $100 \%$ dry matter. ${ }^{2} \mathrm{SE}$ : standard error.

Within the columns, means followed by the same upper-case letter are not different from each other by the Student's test at $\mathrm{p}<0.05$. Within the rows, means followed by the same lower-case letter are not different from each other by the Student's test at $\mathrm{p}<0.05$.

TFM: total forage mass; LY: leaf yield; SY: stem yield; DMY: dead material yield; LSR: leaf-steam ratio; LAI: leaf area index; LI: light interception.

0\%: Xaraés palisade grass under full sun; 30\%: Xaraés palisade grass under 30\% shading; $60 \%$ : Xaraés palisade grass under $60 \%$ shading.

The interval between cuts was longer in the treatment of $60 \%$ shading in the four cutting cycles, as it took longer to reach 95\% LI (Table 1). The reductions in light intensity and temperature caused by the treatment of $60 \%$ shading decreased the photosynthetic potential of forage canopy (MARCELINO et al., 2006). Under reduced luminosity, plants seek light by leaf elevation and stem elongation, providing better radiation distribution through the canopy profile (GOMIDE et al., 2007). As a result of these changes, there was a delay in reaching $95 \% \mathrm{LI}$ in the treatment of $60 \%$ shading, thus increasing stem production.

In the first three cycles, the intervals between cuts in the treatments of 0 and $30 \%$ shading were the same, varying from 25 to 36 days, therefore, reflecting the meteorological conditions during the months of experiment conduction, when temperature and rainfall showed little variation (Figure 1). In the fourth growth cycle, Xaraés grasses under 30\% shading were affected by reductions in minimum temperature and rainfall, in early April, resulting in a longer cycle than that of plants under full sun.

At least one or more factors (shading, cut, and their interaction) had significant effects $(\mathrm{p}<0.05)$ on all the production responses of $U$. brizantha $\mathrm{cv}$. Xaraés (TFM, LY, SY, LSR, and LAI) (Table 2), except for LI that was a parameter to perform forage cuts.

The studied factors (shading and cut) and their interaction had a significant effect $(\mathrm{p}<0.05)$ on TFM, LY, SY, and DMY (Table 2). These yields increased over the cutting cycles, except for the treatment of $60 \%$ light reduction in the last cut, when the four parameters decreased in relation to the third cut. In this treatment, forage cutting was performed during climatic conditions unfavorable to production (Table 2 and Figure 2), namely under lower mean temperatures and poorer rainfall distribution. 
Figure 2. Forage accumulation rate $\left(\mathrm{kg} \mathrm{ha}^{-1}\right.$ day $\left.^{-1} \mathrm{DM}\right)$ of Xaraés palisade grass under three different light intensities.

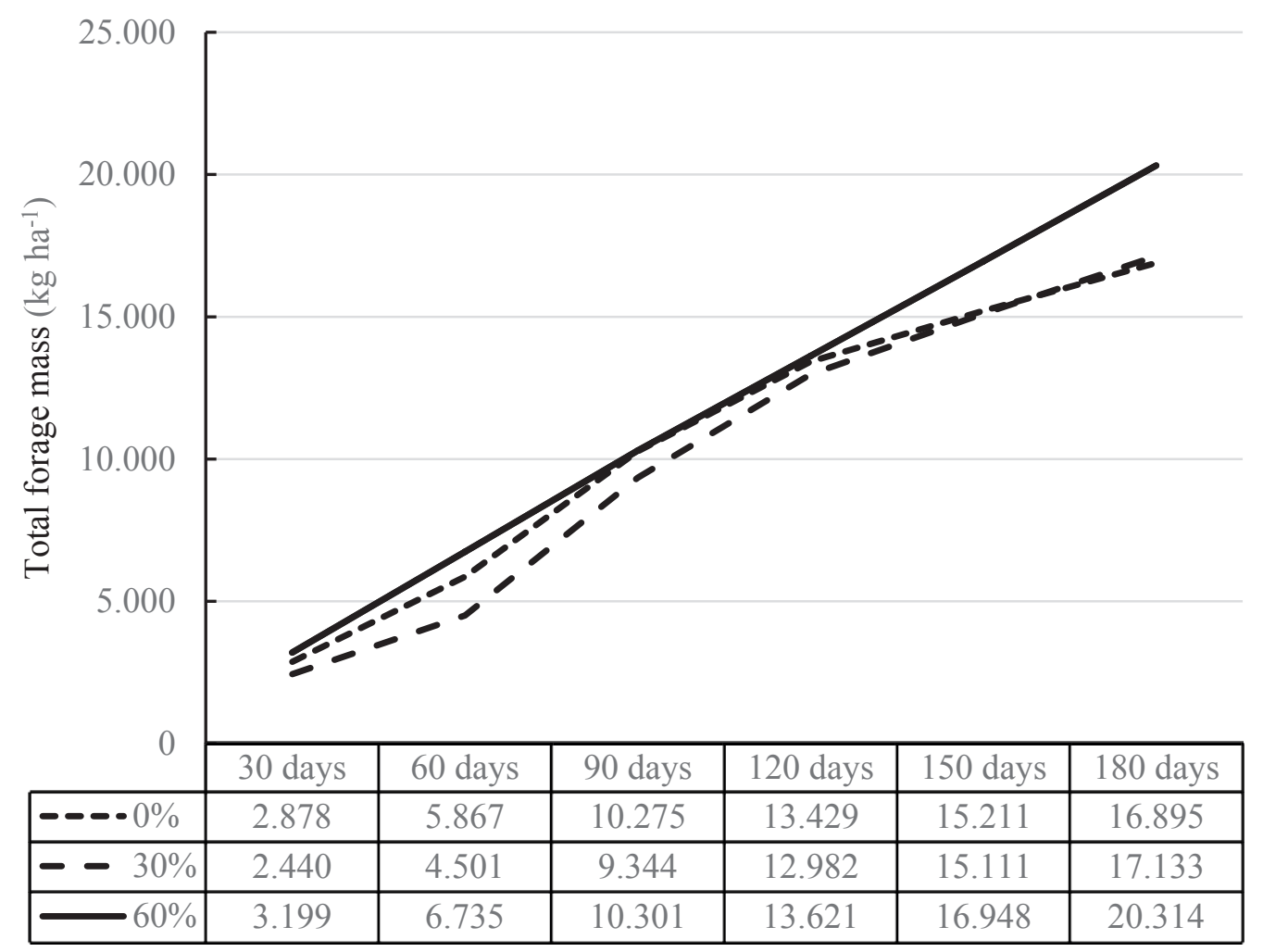

0\%: Xaraés palisade grass under full sun; 30\%: Xaraés palisade grass under 30\% shading; 60\%: Xaraés palisade grass under 60\% shading.

In addition, dead material showed a significantly higher value in the treatment of $60 \%$ light interception when it reached 95\% LI. According to Gomide and Gomide (2000), as new leaves and young tillers appear, competition for growth resources (e.g., light, nutrients, water, among others) increases among forage plants. As a result of selfshading and stem elongation, senescence and death of older leaves and tillers are intensified; under better light conditions, competition is intensified and the percentage of dead material increases.

Under the tested light conditions, the treatment of $60 \%$ light reduction had higher values of TFM, LY, and SY (Table 2), as well as a higher FAR (Figure 2). In this treatment, the delay to reach the recommended LI (95\%) increases the need for a better planning in terms of grazing pressure, paddock number and rotation rate, which directly interfere with annual average production. Higher forage yields may be related to plant effort to produce stems and to change leaf architecture.

To be considered as shade-tolerant, a forage species must have greater or similar yields under both shaded and full-sun conditions (ANDRADE et al., 2004), as observed in our results (Table 2 and Figure 2). Likewise, Souto (2009) and Santos (2014) observed that plants of the genus Urochloa submitted to different levels of artificial shading, in three periods of evaluation, showed a greater production of TFM under $50 \%$ shading.

In grasses with upright growth habit such as cv. Xaraés, stem elongation increases forage production but interferes with pasture structure, which may compromise grazing efficiency due to a decrease in LSR (EUCLIDES et al. 2000). Allied to this, the elongation of stems and leaves favored 
by shading increased SY and LY in the treatment of $60 \%$ shading (Table 2). This high SY may be associated with an increased amount of fiber and lower digestibility since plants under $60 \%$ shading took longer to reach an optimal LAI. Thus, forage nutritive value can be affected by the lower LSR presented by more mature plants, which involves a higher lignification (NAVE, 2010).

The degree of shading had an effect on the leaf area of plants $(\mathrm{p}<0.001)$, the highest LAI values were observed in the treatments of 30 and $60 \%$ light reduction (Table 2). Increases in leaf elongation rates and final leaf-blade lengths per plant have already been reported in grasses subjected to shading (PACIULLO et al., 2008). In fact, when shaded, one of the main responses of plants is to elongate their leaves and stems in an attempt to expose leaves to a higher light intensity.

According to Sousa et al. (2011), morphogenic characteristics and environmental conditions are the main factors that modify the amount of leaf area able to intercept solar radiation. The morphological and structural changes observed in the present study are typical of plants submitted to a low-light environment, as already observed by Gobbi et al. (2009). These results corroborate the statements of Dias Filho (2002) who said that $U$. brizantha plants present phenotypic plasticity and shade tolerance. Similarly, Martuscello et al. (2009) observed that this species has a larger leaf area in a shaded environment, and that the shading tends to induce leaf elongation as a strategy to enhance plant efficiency in light capturing. The same authors, in another study evaluating the production and other agronomic traits of $U$. decumbens cv. Basilisk and $U$. brizantha cvs. Marandu and Xaraés plants under artificial shade, also observed that all plants presented an increase in leaf area as the level of shading increased.

As LAI increases, a larger photosynthetically active area becomes available, and hence a corresponding increase in production rate could occur. As observed in the present study, the shading of $60 \%$ resulted in higher values of TFM, LY, and SY.

\section{Conclusion}

Under the conditions this experiment was conducted, among the studied light intensities, the shading of $60 \%$ promoted the highest production of Xaraés palisade grass.

\section{References}

ANDRADE, C. M. S.; GARCIA, R.; COUTO, L. PEREIRA, O. G.; SOUZA, A. L. Desempenho de seis gramíneas solteiras ou consorciadas com o Stylosanthes guianensis cv. mineirão e eucalipto em sistema silvipastoril. Revista Brasileira de Zootecnia, v. 2 , n .6, p.1845-1850, 2003. DOI: 10.1590/S151635982003000800006

ANDRADE, C. M. S.; VALENTIM, J. F.; COSTA, C. J.; VAZ, F. A. Crescimento de gramíneas e leguminosas forrageiras tropicais sob sombreamento. Pesquisa Agropecuária Brasileira, v. 39, n. 3, p. 263-270, 2004. DOI: 10.1590/S0100-204X2004000300009

BRIGHENTI, A. M.; MUlleR, M. D. Controle do capim-braquiária associado à nutrição com boro no cultivo do mogno-africano em sistema silvipastoril. Revista Ciência Agronômica, v. 45, n. 4, p. 745-751, 2014. DOI: $10.1590 /$ S1806-66902014000400012

COSTA, F. P.; CORRÊA, E. S.; MELO FILHO, G. A.; CARDOSO, E. E.; PEREIRA, M. A.; MIRANDA, C. H. Avaliação dos impactos econômicos de quatro forrageiras lançadas pela Embrapa. Dados eletrônicos. Campo Grande: Embrapa Gado de Corte, 2009. 26 p. (Documentos, 174). Available at: http://old.cnpgc. embrapa.br/publicacoes/doc/DOC174.pdf. Accessed at: 07 jun. 2019.

DIAS FILHO, M. B. Photosynthetic light response of C4 grasses Brachiaria brizantha and Brachiaria humidicola under shade. Scientia Agricola, v. 59, n. 1, p. 65-68, 2002. DOI: $10.1590 / \mathrm{S} 0103-90162002000100009$

EMPRESA BRASILEIRA DE PESQUISA AGROPECUÁRIA - EMBRAPA. Manual de métodos de análises de solos. 2. ed. Rio de Janeiro: Embrapa Solos, 2011. $230 \mathrm{p}$.

EMPRESA BRASILEIRA DE PESQUISA AGROPECUÁRIA - EMBRAPA. Sistema brasileiro 
de classificação de solos. SiBCs. 3. ed. Rio de Janeiro: Embrapa Solos, 2013. 353 p.

EUCLIDES, V. P. B.; CARDOSO, E. G.; MACEDO, M. C. M.; OLIVEIRA, M. P. Consumo voluntário de Brachiaria decumbens cv. Basilisk e Brachiaria brizantha cv. Marandu sob pastejo. Revista Brasileira de Zootecnia, v. 29, n. 6, p. 2200-2208, 2000. Available at: http://www.sbz.org.br/revista/artigos/2660.pdf Accessed at: 03 july. 2019 .

FRANKE, I. L.; LUNZ, A. M. P.; VALENTIM, J. F.; AMARAL, E. F.; MIRANDA, E. M. Situação atual e potencial dos sistemas silvipastoris no estado do Acre. In: CARVALHO, M. M.; ALVIM, M. J.; CARNEIRO, J. C. (Ed.). Sistemas agroflorestais pecuários: opções de sustentabilidade para áreas tropicais e subtropicais. Juiz de Fora: Embrapa-CNPGL; FAO, 2001, p. 19-40.

GOBBI, K. F.; GARCIA, R.; GARCEZ NETO, A. F.; PEREIRA, O. G.; VENTRELLA, M. C.; ROCHA, G. C. Características morfológicas, estruturais e produtividade do capim-braquiária e do amendoim forrageiro submetidos ao sombreamento. Revista Brasileira de Zootecnia, Viçosa, v. 38, n. 9, p. 1645-1654, 2009. DOI: 10.1590/S1516-35982009000900002

GOMIDE, C. A. M.; GOMIDE, J. A. Morfogênese de cultivares de Panicum maximum (Jacq.). Revista Brasileira de Zootecnia, Viçosa, v. 29, n. 2, p. 341-348, 2000. DOI: $10.1590 /$ S1516-35982000000200004

GOMIDE, C. A. M.; GOMIDE, J. A.; ALEXANDRINO, E. Características estruturais e produção de forragem em pastos de capim-mombaça submetidos a períodos de descanso. Pesquisa Agropecuária Brasileira, v. 42, n. 10 , p. 1487-1494, 2007. DOI: 10.1590/S0100204X2007001000017

INSTITUTO BRASILEIRO DE GEOGRAFIA E ESTATÍSTICA - IBGE. Censo Agropecuário 2017 Divulgação preliminar. 2018. Available at: https:// agenciadenoticias.ibge.gov.br/media/com_mediaibge/ arquivos/8510fa66acebe7034165215eb169b6ab.pdf. Accessed at: 11 sept. 2018.

JANK, L.; VALLE, C. B. do; RESENDE, R. M. S. Grass and forage plant improvement in the tropics and subtropics. In: MCGILLOWAY, D. A. (Ed.). Grassland: a global resource. Wageningen: Wageningen Academic Publishers. 2005, p. 69-81.

MARCELINO, K. R. A.; JUNIOR, D. N.; SILVA, S. C.; EUCLIDES, V. P. B.; FONSECA, D. M. Características morfogênicas e estruturais e produção de forragem do capim marandu submetido a intensidades e freqüências de desfolhação. Revista Brasileira de Zootecnia, v. 35, n. 6, p. 2243-2252, 2006. DOI: 10.1590/S1516-

\section{7}

MARTUSCELLO, J. A.; JANK, L.; GONTIJO NETO, M. M.; LAURA, V. A.; CUNHA, D. N. F. V. Produção de gramíneas do gênero Brachiaria sob níveis de sombreamento. Revista Brasileira de Zootecnia, v. 38, n. 7, p.1183-1190, 2009. DOI: 10.1590/ S151635982009000700004

MÜller, M. D.; NOGUEIRA, G. S.; CASTRO, C. R. T. de; PACIULlO, D. S. C.; ALVES, F. F.; CASTRO, R. V. O.; FERNANDES, E. N. Economic analysis of an agrosilvipastoral system for a mountainous area in Zona da Mata Mineira, Brazil. Pesquisa Agropecuária Brasileira, v. 46, n. 10, p. 1148-1153, 2011. DOI: 10.1590/S0100-204X2011001000005

NAVE, R. L. G.; PEDREIRA, C. G. S.; PEDREIRA, B. C. Nutritive value and physical characteristics of Xaraes palisadegrass as affected by grazing strategy. South African Journal of Animal Science, v. 40, n. 4, p. $285-$ 293, 2010. DOI: 10.4314/sajas.v40i4.65236

NEVES, C. M. N.; SILVA, M. L. N.; CURI, N.; MACEDO, R. L. G.; MOREIRA, F. M. S.; D'ANDRÉA, A. F. Indicadores biológicos da qualidade do solo em sistema agrossilvipastoril no noroeste do estado de Minas Gerais. Ciência e Agrotecnologia, Lavras, v. 33, n. 1, p. 105-112, 2009. DOI: $10.1590 / \mathrm{S} 1413-70542009000100015$

PACIULLO, D. S. C.; CAMPOS, N. R.; GOMIDE, C. A. M.; CASTRO, C. R. T.; TAVELA R. C.; ROSSIELLO, R. O. P. Growth of signalgrass influenced by shading levels and season of the year. Pesquisa Agropecuária Brasileira, v. 43, n. 7, 917-923, 2008. DOI: 10.1590/ S0100-204X2008000700017

PACIULlO, D. S. C.; CASTRO, C. R. T.; GOMIDE, C. A. M.; MAURÍCIO, R. M.; PIRES, M. F. A.; MÜLLER, M. D.; XAVIER, D. F. Performance of dairy heifers in a silvopastoral system. Livestock Science, v. 141, n. 2-3, p. 166-172, 2011. DOI: 10.1016/j.livsci.2011.05.012

SANTOS, C. G. Avaliação de gramíneas forrageiras tropicais em diferentes níveis de sombreamento. Revista Científica de Produção Animal, v. 16, n. 1, 68-78, 2014. DOI: 10.15528/2176-4158/rcpa.v16n1p68-78

SOUSA, B. M. L.; NASCIMENTO JÚNIOR, D.; RODRIGUES, C. S.; MONTEIRO, H. C. F.; SILVA, S. C.; FONSECA, D. M.; SBRISSIA, A. F. Morphogenetic and structural characteristics of xaraes palisadegrass submitted to cutting heights. Revista Brasileira de Zootecnia, v. 40, n. 1, p. 53-59, 2011. DOI: 10.1590/ S1516-35982011000100008

SOUTO, S. M.; DIAS, P. F.; VIEIRA, M. S.; DIAS, J.; SILVA, L. L. G. G. Comportamento de plantas 
de Brachiaria brizantha cv. Xaraés submetidas ao sombreamento. Revista Ciência Agronômica, v. 40, n. 2, p. 279-286, 2009. Available at: http://ccarevista.ufc.br/ seer/index.php/ccarevista/article/view/522/340 Accessed at: 03 july. 2019 .

STATISTICALANALYSIS SYSTEM - SAS. Base SAS 9.4 Procedures Guide. Cary: SAS Institute, 2014.
VALLE, C. B. do; EUCLIDES, V. P. B.; PEREIRA, J. M.; VALÉRIO, J. R.; PAGLIARINI, M.S.; MACEDO, M. C. M.; LEITE, G.G.; LOURENÇO, A. J.; FERNANDES, C. D.; DIASFILHO, M.B.; LEMPP, P. A.; SOUZA, M. A. O capim-xaraés (Brachiaria brizantha $c v$. Xaraés) na diversificação das pastagens de braquiária. Campo Grande: Embrapa Gado de Corte. 2004, 36 p. (Documentos, 149). 